(C) 2021, The Authors. Published by Elsevier Inc. and Fass Inc. on behalf of the American Dairy Science Association ${ }^{\circledR}$. This is an open access article under the CC BY-NC-ND license (http://creativecommons.org/licenses/by-nc-nd/4.0/).

\title{
Antimicrobial resistance and virulence characteristics in 3 collections of staphylococci from bovine milk samples
}

\author{
M. E. Fergestad, ${ }^{1}$ A. De Visscher, ${ }^{2 *}$ T. L'Abee-Lund, ${ }^{1}$ C. Ngassam Tchamba, ${ }^{3}$ J. G. Mainil, ${ }^{3}$ D. Thiry, ${ }^{3}$ \\ S. De Vliegher, ${ }^{2}$ and $Y$. Wasteson ${ }^{1} \dagger$ \\ ${ }^{1}$ Department of Paraclinical Sciences, Faculty of Veterinary Medicine, Norwegian University of Life Sciences, 0454 Oslo, Norway \\ ${ }^{2} \mathrm{M}$-team and Mastitis and Milk Quality Research Unit, Department of Reproduction, Obstetrics, and Herd Health, Faculty of Veterinary Medicine, \\ Ghent University (UGent), 9820 Merelbeke, Belgium \\ ${ }^{3}$ Bacteriology, Department of Infection Diseases, Faculty of Veterinary Medicine, Fundamental and Applied Research \\ in Animal and Health (FARAH) Centre, University of Liège (ULiège), 4000 Liège, Belgium
}

\begin{abstract}
Mastitis is a prevalent disease in dairy cattle, and staphylococci are among the most common causative pathogens. Staphylococci can express resistance to a range of antimicrobials, of which methicillin resistance is of particular public health concern. Additionally, Staphylococcus aureus carries a variety of virulence factors, although less is understood about the virulence of non-aureus staphylococci (NAS). The aim of our study was to identify and characterize 3 collections of staphylococcal isolates from bovine milk samples regarding antimicrobial resistance, with emphasis on methicillin resistance, and their carriage of virulence genes typically displayed by Staph. aureus. A total of 272 staphylococcal isolates collected in Norway and Belgium in 2016 were included, distributed as follows: group 1, Norway, 100 isolates; group 2, Flanders, Belgium, 64 isolates; group 3, Wallonia, Belgium, 108 isolates. Species identification was performed by use of MALDI-TOF mass spectrometry. Phenotypic resistance was determined via disk diffusion, and PCR was used for detection of methicillin resistance genes, mecA and mecC, and virulence genes. Antimicrobial resistance was common in Staphylococcus epidermidis and Staphylococcus haemolyticus from all different groups, with resistance to trimethoprim-sulfonamide frequently occurring in Staph. epidermidis and Staph. haemolyticus as well as in Staph. aureus. Resistance to penicillin was most frequently observed in group 1. Ten Belgian isolates (1
\end{abstract}

Received December 2, 2020.

Accepted March 27, 2021.

*Present address: Flanders Research Institute for Agriculture, Fisheries and Food (ILVO), Technology and Food Science, Agricultural Engineering, Burg. Van Gansberghelaan 115 bus 1, 9820 Merelbeke, Belgium

†Corresponding author: yngvild.wasteson@nmbu.no from group 2, 9 from group 3) carried the methicillin resistance determinant mecA: 5 Staph. aureus from 2 different farms and 5 NAS from 3 different farms. Almost all Staph. aureus isolates were positive for at least 3 of the screened virulence genes, whereas, in total, only 8 NAS isolates harbored any of the same genes. Our study contributes to the continuous need for knowledge regarding staphylococci from food-producing animals as a basis for better understanding of occurrence of resistance and virulence traits in these bacteria.

Key words: Staphylococcus aureus, non-aureus staphylococci, antimicrobial resistance, virulence genes, bovine mastitis

\section{INTRODUCTION}

Mastitis is a common disease in dairy cattle, affecting animal health and welfare, and dairy farm profitability (Halasa et al., 2007; Rollin et al., 2015). Staphylococci are among the most recognized udder pathogens, of which Staphylococcus aureus is an important cause of subclinical and clinical mastitis in dairy cattle, with its importance in the context of mastitis and milk quality varying by region and farm (Østerås et al., 2006; Olde Riekerink et al., 2008; Gao et al., 2017). In a Belgian study, Staph. aureus was isolated from $7.3 \%$ of the clinical mastitis cases in Flemish dairy herds (Verbeke et al., 2014), whereas in a Norwegian study Staph. aureus was found in $45.8 \%$ of the clinical mastitis cases from heifers (Waage et al., 1999). In contrast, NAS are the most frequently isolated bacteria causing subclinical mastitis. Their role as mastitis-causing pathogens is debatable, but in general they are associated with moderately increased SCC (Piepers et al., 2007; De Vliegher et al., 2012; De Visscher et al., 2016; Valckenier et al., 2019). A negative effect on milk production after infection has been reported (Heikkilä et al., 2018), although others have reported differently (Valckenier et al., 2019). The distribution of NAS species in milk 
samples is described in several studies; however, the results are not directly comparable due to a variety of study designs. A recent study from Belgium concluded that the 5 most prevalent NAS species recovered from quarter milk samples were Staphylococcus chromogenes, Staphylococcus haemolyticus, Staphylococcus equorum, Staphylococcus hominis, and Staphylococcus cohnii (Wuytack et al., 2020). In Norway, Staphylococcus epidermidis and Staph. aureus are currently regarded as the most common staphylococcal udder pathogens (Dalen et al., 2019).

Most of the antimicrobial usage in dairy production concerns udder health (Saini et al., 2012; Nobrega et al., 2017). The largest proportion is administered for the intramammary treatment of clinical mastitis and dry cow therapy (De Briyne et al., 2014; Stevens et al., 2016; Stevens et al., 2018). In general terms, treatment with antimicrobials is regarded as the main driver for antimicrobial resistance, although the association between antimicrobial use and corresponding resistance is less compelling in the case of mastitis (Tacconelli, 2009; Oliver and Murinda, 2012).

Methicillin-resistant Staph. aureus (MRSA) is classified as a high-priority pathogen by WHO and has gained most attention among the resistant staphylococci. However, methicillin resistance has also been described in several species of the NAS group (Feßler et al., 2010; Gindonis et al., 2013), and NAS are thought to be a reservoir for numerous resistance genes that could be transferred into the more pathogenic Staph. aureus (Becker et al., 2014). Methicillin-resistant staphylococci are resistant to almost all $\beta$-lactams, and infections caused by these bacteria result in limited treatment options, delayed initiation of effective treatment, and poorer outcomes (Yaw et al., 2014). When it comes to MRSA as cause of mastitis, Norway may be regarded as a naive country, as MRSA has been associated with bovine mastitis on only 1 occasion (NORM/ NORM-VET, 2015). This contrasts with the current situation in Belgium, where MRSA is an established cause of clinical mastitis. Bardiau et al. (2013) found MRSA in $4.4 \%$ of milk samples from bovine mastitis, and Vanderhaeghen et al. (2010) found 9.3\% of Staph. aureus isolates to be MRSA in milk samples from farms experiencing Staph. aureus mastitis.

Staphylococci are well known for their carriage of a range of other resistance determinants in addition to the methicillin resistance trait, often occurring in different combinations, giving rise to multidrug-resistant isolates (Kadlec et al., 2012; Wendlandt et al., 2015; Schoenfelder et al., 2017). An important aspect of the antimicrobial resistance challenge is that resistant staphylococci from animals may pose a threat to public health due to the possible transfer from their different reservoirs to humans (Lee, 2003), and the possible transmission and spread of resistance genes between staphylococci (Levy and Marshall, 2004; Hanssen and Ericson Sollid, 2006). VetPath, a pan-European antimicrobial susceptibility monitoring program, has recently reported data on antimicrobial susceptibility of 9 udder pathogens from bovine mastitis in Europe from 2015 to 2016 , and on an overall level they report low resistance to antimicrobials and a low prevalence of MRSA (El Garch et al., 2020).

Mastitis-related Staph. aureus are also associated with a variety of virulence factors that play an important role in the pathogenesis of mastitis. These include, among others, cell wall-associated factors, different enzymes, and exotoxins that facilitate the infection pathway. The NAS species lack the aggressive potential of Staph. aureus, and less is known about the virulence of these species (Becker et al., 2014; Naushad et al., 2019; Wuytack et al., 2020). Knowledge regarding virulence of both Staph. aureus and NAS species associated with bovine mastitis, especially in combination with resistance patterns, is important for designing efficient prophylaxis and treatment guidelines.

The aim of this study was to gain knowledge on resistance and virulence characteristics of 3 groups of mastitis-associated Staph. aureus and NAS isolates from bovine milk samples collected in Norway and Belgium as part of an international collaboration. The objectives were (1) to characterize the isolates with regard to their antimicrobial resistance properties, with emphasis on methicillin resistance, (2) to determine carriage of genes encoding known Staph. aureus virulence factors in all 3 Staph. aureus and NAS isolate collections, and (3) to analyze for correlation patterns of resistance and of virulence of the collected isolates.

\section{MATERIALS AND METHODS}

\section{Collection of Staphylococcal Isolates}

The isolates were collected as 3 unique collections, all being part of a larger European collaboration. The 3 different sampling strategies, ensuring diversity of the material and at the same time conveniently adapted to the national structures of dairy production, the framework, and the resources of the collaborative project, are described in Table 1. Table 1 also contains information about characteristics of the sampled farms. The aim was to collect a total of 300 staphylococcal isolates: 100 from Norway and 200 from Belgium. The ratio between Staph. aureus and NAS was defined a priori to be 1:5. All sampling was performed in 2016. 
Fergestad et al.: AMR AND VIRULENCE IN BOVINE STAPHYLOCOCCI

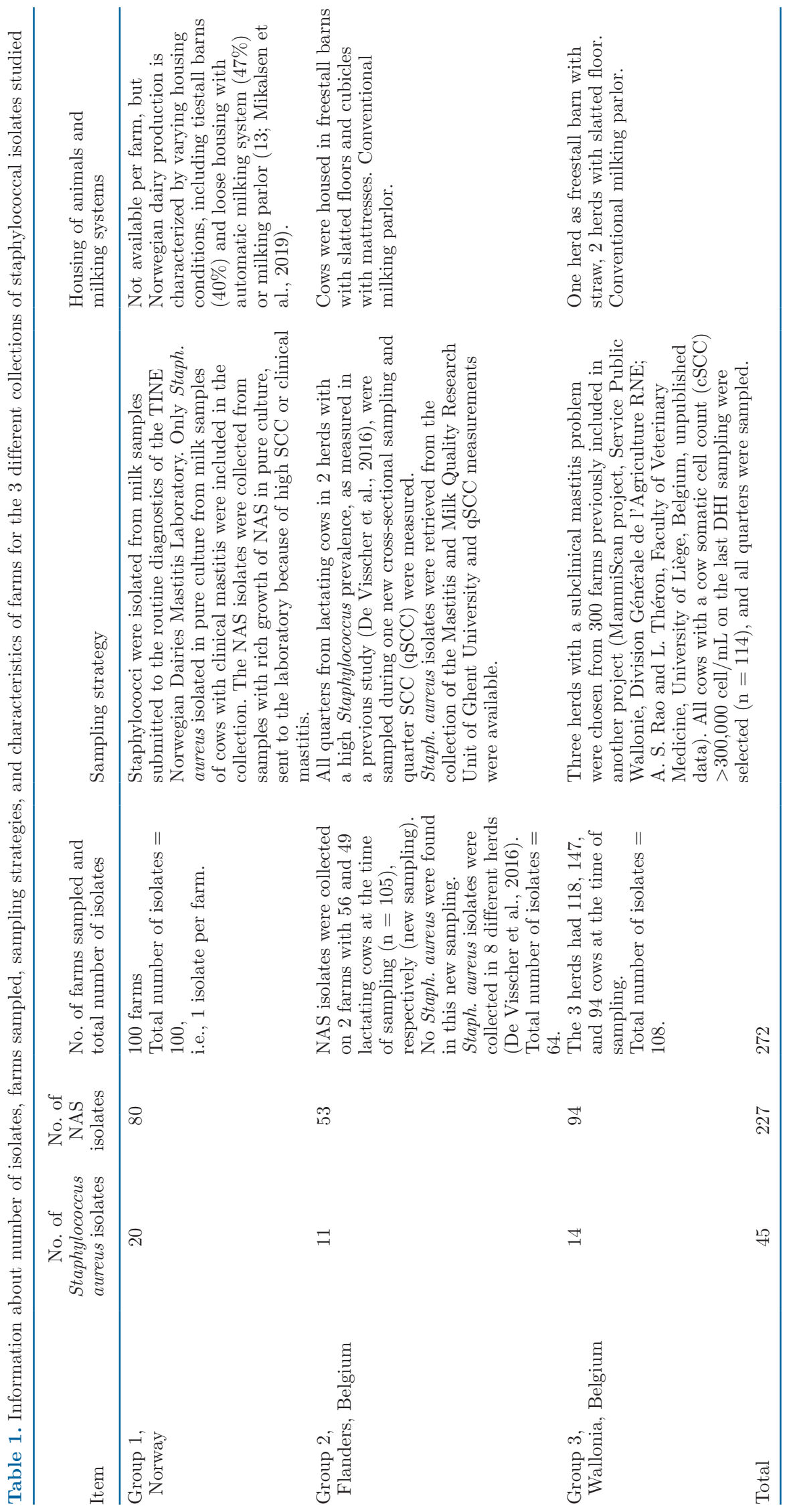




\section{Isolation and Identification} of Staphylococcus Isolates

First, $10 \mu \mathrm{L}$ of each quarter milk sample were plated on a quadrant of a Columbia agar supplemented with $5 \%$ sheep blood (Oxoid) for samples from group 2 and 3 , and Difco heart infusion agar with $5 \%$ washed bovine erythrocytes (BD Biosciences) for samples from group 1 , both nonselective media. For groups 2 and 3, modified Chapman's agar or mannitol salt agar, a semiselective medium, were also used for the recovery of staphylococci (Oxoid). Plates were examined after 24-h aerobic incubation at $37^{\circ} \mathrm{C}$. If more than 2 phenotypically different colony types were present on blood agar, the quarter milk sample was considered contaminated and rejected. If not, for samples from group 2 and 3 all phenotypically different colony types were counted on mannitol salt agar and subcultured (1 colony per colony type) on blood agar (Columbia agar with 5\% sheep blood, Oxoid), whereas for group 1 all suspected staphylococcal colonies on blood agar, based on colony morphology and catalase test, were subcultured ( 1 colony per colony type) on blood agar (Difco heart infusion agar with 5\% washed bovine erythrocytes, BD Biosciences) to obtain pure cultures (aerobic incubation at $37^{\circ} \mathrm{C}$, a half plate per colony). The previously mentioned procedures were performed at the laboratories at the place of collection (TINE Norwegian Dairies Mastitis Laboratory, Ghent University, and University of Liège). Pure cultures were examined as described by De Visscher et al. (2013). All suspected staphylococci were stored at $-80^{\circ} \mathrm{C}$ in Microbank cryovials (Pro-Lab Diagnostics) and identified at the species level using MALDI-TOF MS and a validated and updated library for bovine-related NAS species (Cameron et al., 2017, 2018). If no identification could be assigned using MALDI-TOF MS, DNA was subjected to sequencing of the rpoB gene (Supré et al., 2009). The examination of pure cultures and species identification with MALDI-TOF MS (or the rpoB gene) for all groups were performed at Ghent University.

\section{DNA Extraction}

Bacterial DNA was extracted using the following procedure, based on Unal et al. (1992): 1 or 2 colonies of each Staphylococcus isolate were mixed with $3 \mathrm{~mL}$ of brain heart infusion broth (Oxoid) and aerobically incubated at $37^{\circ} \mathrm{C}$ overnight. Then $100 \mu \mathrm{L}$ of each bacterial suspension was centrifuged at $16,500 \times g$ for 3 min (Thermo Scientific Heraeus Pico 21 microcentrifuge). The supernatant was removed, and the pellet was resolved with $50 \mu \mathrm{L}$ of lysostaphin $(50 \mu \mathrm{g} / \mathrm{mL})$. The tubes were heated at $37^{\circ} \mathrm{C}$ for $10 \mathrm{~min}$ before adding $50 \mu \mathrm{L}$ of proteinase $\mathrm{K}(100 \mu \mathrm{g} / \mathrm{mL})$ and $150 \mu \mathrm{L}$ of 0.1
$M$ Tris ( $\mathrm{pH} \mathrm{7.5),} \mathrm{and} \mathrm{then} \mathrm{heated} \mathrm{at} 37^{\circ} \mathrm{C}$ for $10 \mathrm{~min}$ and $95^{\circ} \mathrm{C}$ for $5 \mathrm{~min}$. The extracted DNA was stored at $-20^{\circ} \mathrm{C}$ before analyses.

\section{Phenotypic Antimicrobial Resistance Testing}

Antimicrobial resistance was determined by means of the disk diffusion method by Bauer et al. (1966) and according to the methodology recommended by the European Committee on Antimicrobial Susceptibility Testing (www.eucast.org, accessed Aug. 2018), except that Mueller Hinton broth was used instead of saline water for the bacterial suspension, corresponding to 0.5 McFarland for the panel of antimicrobial agents. The following antimicrobial agents were included in the test panel: ampicillin $(10 \mu \mathrm{g})$, amoxicillin and clavulanic acid $(20+10 \mu \mathrm{g})$, ciprofloxacin $(5 \mu \mathrm{g})$, clindamycin $(10 \mu \mathrm{g})$, erythromycin $(15 \mu \mathrm{g})$, gentamicin $(10 \mu \mathrm{g})$, linezolide $(10 \mu \mathrm{g})$, penicillin (1 U), trimethoprim (5 $\mu \mathrm{g})$, sulfonamide and trimethoprim $(19: 1,25 \mu \mathrm{g})$, and tetracycline $(30 \mu \mathrm{g})$. Cefoxitin $(30 \mu \mathrm{g})$ was used for determination of phenotypic methicillin resistance, as recommended by the European Committee on Antimicrobial Susceptibility Testing (EUCAST, www.eucast .org). Categorization of the isolates as resistant or intermediate (assigned as resistant) versus susceptible was based on clinical breakpoints determined by EUCAST; these breakpoints are prepared for human strains and not mastitis pathogens. Species-specific breakpoints for the NAS group are scarce, so the general breakpoints for coagulase-negative staphylococci were used.

\section{Genotypic $\beta$-Lactam Resistance Testing}

The PCR for detection of mecA and mecC was carried out as described by Stegger et al. (2012) to test for $\beta$-lactam resistance (methicillin resistance). Genes, primer sequences, amplicon sizes, and annealing temperatures are listed in Table 2. A mecA-positive Staph. aureus isolate previously confirmed using DNA sequencing (NMBU2664/16, Routine Microbiology Laboratory, Faculty of Veterinary Medicine, Norwegian University of Life Science) and Staph. aureus NTCT 13552 were included as positive controls in the mecA and mec $C$ PCR, respectively. Sterile water was used as negative control.

\section{Virulence Genes}

Nine virulence genes common in Staph. aureus were selected for PCR analysis, based on a review of relevant articles available in the PubMed database in November and December 2016. The chosen genes were clf $A$ (clumping factor), $f n b p A$ and $f n b p B$ (fibronectin-bind- 


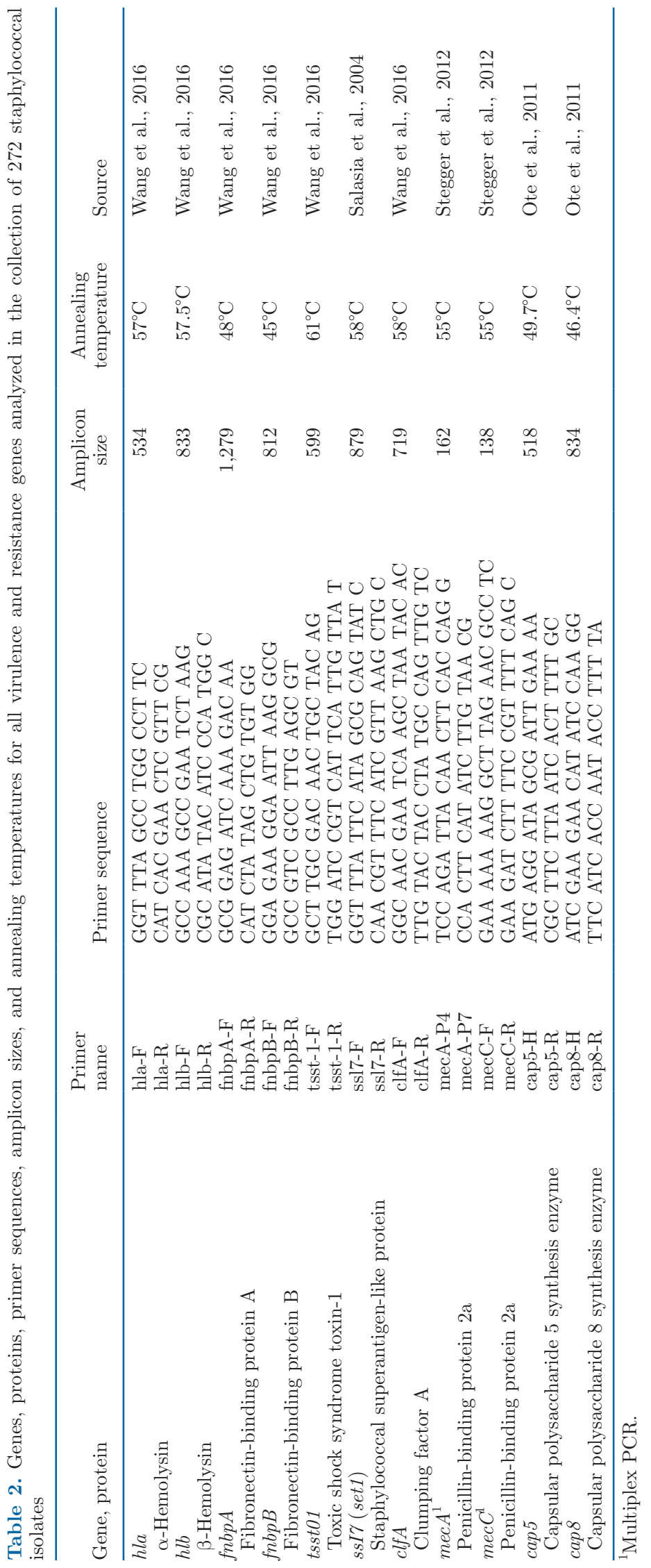


ing proteins), hla and hlb (hemolysins), tsst01 (toxic shock syndrome toxin-1), ssly (set1, staphylococcal superantigen-like protein), cap5 (CP5 capsule synthesis enzyme), and cap8 (CP8 capsule synthesis enzyme; Salasia et al., 2004; Ote et al., 2011; Wang et al., 2016). The PCR were carried out using the protocol of Wang et al. (2016) for clfA, $f n b p A, f n b p B$, hla, hlb, and tsst01, according to Salasia et al. (2004) for ssl\%, and according to Ote et al. (2011) for cap5 and cap8.

Genes, primer sequences, amplicon sizes, and annealing temperatures are listed in Table 2. Because positive controls were not available for any of the virulence genes except cap 5 and cap8, the amplified PCR products from 1 isolate positive for all the remaining tested virulence genes was confirmed by DNA sequencing, using Sanger sequencing (GATC, Eurofins Genomics) of each gene, and the DNA from the confirmed isolate was further used as positive control. For cap 5 and cap 8 , previously published positive strains B34 and B79 were used as positive controls (Ote et al., 2011). Sterile water was used as negative control.

\section{Correlation Plots}

Correlation plots were created in $\mathrm{R}$ 3.6.2 ( $\mathrm{R}$ Core Team, 2013) using the corrplot (Wei and Simko, 2017) package v. 0.84 . We considered 2 variables with a phi coefficient greater than 0.7 to be strongly correlated. The correlations that were calculated were correlations between resistance genes in Staph. aureus, between resistance genes in NAS, and between virulence genes in Staph. aureus. Correlation between virulence genes in NAS was not calculated, due to the low number of virulence genes detected.

\section{RESULTS}

\section{Staphylococcus Species Identification}

A total of 272 Staphylococcus isolates from 319 cattle, collected in Norway (group 1, 100 isolates/100 cattle), Flanders (group 2, 64 isolates/105 cattle), and Wallonia (group 3, 108 isolates/114 cattle), were collected, and all were included in the study. After analysis with MALDI-TOF MS, the following Staphylococcus species were most frequently $(\geq 10 \%)$ identified: in group 1 Staphylococcus simulans $(\mathrm{n}=29)$, Staph. chromogenes $(\mathrm{n}=25)$, Staph. aureus $(\mathrm{n}=20)$, and Staph. epidermidis $(\mathrm{n}=13)$; in group 2: Staph. chromogenes $(\mathrm{n}=$ 15), Staph. haemolyticus $(\mathrm{n}=11)$, Staph. aureus $(\mathrm{n}=$ 11), and Staph. cohnii $(\mathrm{n}=8)$; and in group 3: Staph. epidermidis $(\mathrm{n}=19)$, Staph. chromogenes $(\mathrm{n}=17)$, Staph. haemolyticus $(\mathrm{n}=15)$, and Staph. aureus $(\mathrm{n}=$
14). The full species distribution in relation to each group is shown in Figure 1.

\section{Phenotypic Antimicrobial Resistance}

Species distribution and number of isolates categorized as resistant toward the panel of antimicrobials tested are shown in Table 3. Antimicrobial resistance was most common in Staph. haemolyticus and Staph. epidermidis in all 3 sample groups.

Group 1. All 3 Staph. haemolyticus isolates and $77 \%$ of the Staph. epidermidis isolates $(\mathrm{n}=10)$ from group 1 showed resistance to at least 1 of the tested antimicrobials. Resistance to penicillin was more frequently observed, except in the Staph. simulans isolates, in which resistance to trimethoprim was most common. Staphylococcus epidermidis was the only species of which more than $50 \%$ of the isolates were resistant, as $54 \%$ were resistant to penicillin. However, no resistance to cefoxitin was observed in this collection. Neither were any isolates categorized as multidrug resistant, defined as resistance to 3 or more of the tested classes of antimicrobials. Isolates fully susceptible toward the tested antimicrobials were distributed as follows: Staph. chromogenes 17/25, Staph. aureus 16/20, Staph. simulans 14/29, Staph. epidermidis 3/13, Staphylococcus hyicus 4/4, and Staphylococcus devriesei 2/2.

Group 2. Eleven Staph. haemolyticus isolates (91\%) and the single Staph. epidermidis isolate in group 2 showed resistance to at least 1 of the tested antimicrobials. Resistance to trimethoprim and trimethoprimsulfonamide were most common, as, in most species including trimethoprim and trimethoprim-sulfonamideresistant isolates, at least $50 \%$ of the isolates were categorized as resistant. Resistance toward cefoxitin was observed in 3 different species: Staph. cohnii, Staph. aureus, and Staphylococcus sciuri; and 18 isolates were multidrug resistant. The multidrug-resistant isolates included the following species: Staph. cohnii $(\mathrm{n}=5)$, Staph. chromogenes $(\mathrm{n}=3)$, Staph. equorum $(\mathrm{n}=3)$, Staphylococcus arlettae $(\mathrm{n}=2)$, Staph. haemolyticus (n $=2)$, Staph. sciuri $(\mathrm{n}=2)$, and Staph. aureus $(\mathrm{n}=1)$. Isolates fully susceptible toward the tested antimicrobials were distributed as follows: Staph. chromogenes 5/15, Staph. aureus 3/12, and Staph. haemolyticus 1/11.

Group 3. All Staph. haemolyticus isolates $(\mathrm{n}=15)$ and all Staph. epidermidis isolates $(\mathrm{n}=19)$ in group 3 showed resistance to at least 1 of the tested antimicrobials. Also, in group 3, resistance to trimethoprim and trimethoprim-sulfonamide were most observed. Resistance toward cefoxitin was observed in 9 different species, including Staph. aureus, Staph. chromogenes, Staph. epidermidis, and Staph. haemolyticus. A total of 24 isolates were multidrug resistant, represented by the 
25

- Group 1 Group 2 m Group 3

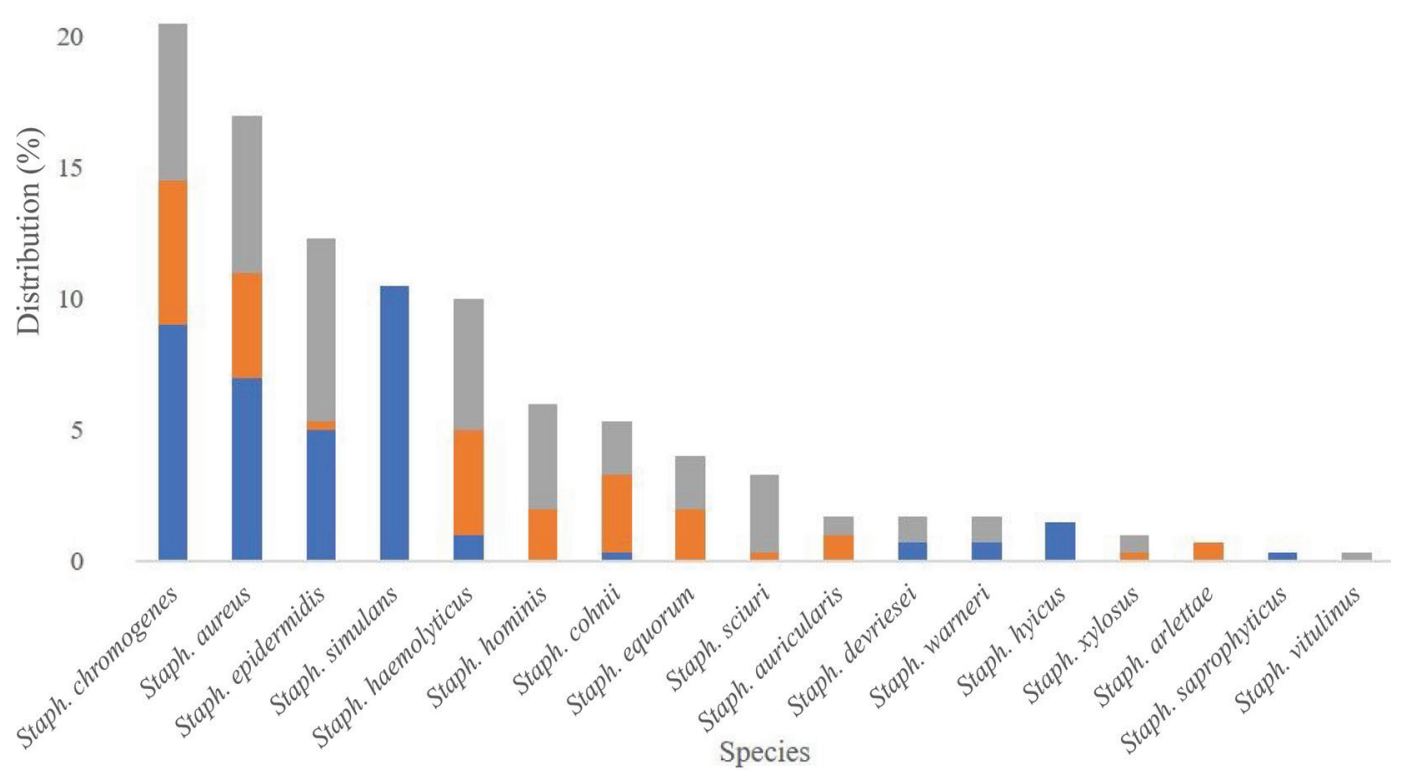

Figure 1. Staphylococcus species distribution for the collection of 272 staphylococcal isolates by group, shown as percentage of the total number of isolates. Group 1: collected in Norway; milk samples from quarters with mastitis or high SCC, all different herds. Group 2: collected in Flanders, Belgium; 53 NAS isolates from milk samples from all quarters from all cows (105 dairy cows) from 2 different herds, and 11 Staphylococcus aureus isolates from 8 additional herds. Group 3: collected in Wallonia. Belgium; milk samples from all quarters from 114 dairy cows with composite cow SCC $>300,000$ cells $/ \mathrm{mL}$ from 3 different herds.

following species: Staph. epidermidis $(\mathrm{n}=5)$, Staph. aureus $(\mathrm{n}=4)$, Staph. haemolyticus $(\mathrm{n}=4)$, Staph. sciuri $(\mathrm{n}=4)$, Staph. cohnii $(\mathrm{n}=3)$, Staphylococcus warneri $(\mathrm{n}=3)$, and Staph. hominis $(\mathrm{n}=1)$. Of these, originating from the same farm, 1 Staph. epidermidis isolate had 9 and 2 Staph. aureus isolates had 8 observations of resistance toward the panel of tested antimicrobials. This Staph. epidermidis isolate was the only isolate phenotypically resistant toward linezolid (Table 3). Isolates fully susceptible toward the tested antimicrobials were distributed as follows: Staph. aureus 4/16 and Staph. chromogenes $3 / 17$.

Figure 2 and Figure 3 show the correlations between the different observed resistances for Staph. aureus and the NAS species, respectively. The correlation plots revealed a strong correlation between resistance to trimethoprim and trimethoprim-sulfonamide and between resistance to clindamycin and erythromycin. In addition, we found a stronger correlation between several resistance observations in Staph. aureus compared with the NAS species as a group.

\section{Characterization of Isolates with mec Genes}

Group 1. No isolates in group 1 were positive for the mec genes.
Group 2. The only mecA-positive isolate in group 2 was a Staph. aureus isolate, which showed resistance to cefoxitin on disk diffusion, as well as resistance to penicillin, ampicillin, and amoxycillin-clavulanic acid, as well as 4 other antimicrobials, as shown in Table 4. No isolates were positive in the mecC PCR.

Group 3. In group 3, 4 Staph. aureus isolates and 5 NAS isolates were positive in the PCR for the mecA gene, but none in the mec $C$ PCR. These mecA-positive Staph. aureus isolates (hereafter referred to as MRSA) originated from the same farm and were thus epidemiologically related. They showed resistance to cefoxitin on disk diffusion; 3 showed resistance to ampicillin; and 2 showed resistance toward amoxicillin-clavulanic acid. These isolates were also multidrug resistant and showed resistance toward 6 or more of the tested antimicrobials. Many of the observed resistances in Staph. aureus isolates were traced to these 5 isolates.

The 5 mecA-positive NAS belonged to 5 different species: Staph. epidermidis, Staph. haemolyticus, Staph. sciuri, Staphylococcus vitulinus, and Staphylococcus xylosus. The Staph. haemolyticus originated from the same farm as the MRSA, whereas Staph. epidermidis came from another farm, and the Staph. sciuri, Staph. vitulinus, and Staph. xylosus from the same third farm. Only the Staph. haemolyticus and Staph. epidermi- 
Fergestad et al.: AMR AND VIRULENCE IN BOVINE STAPHYLOCOCCI

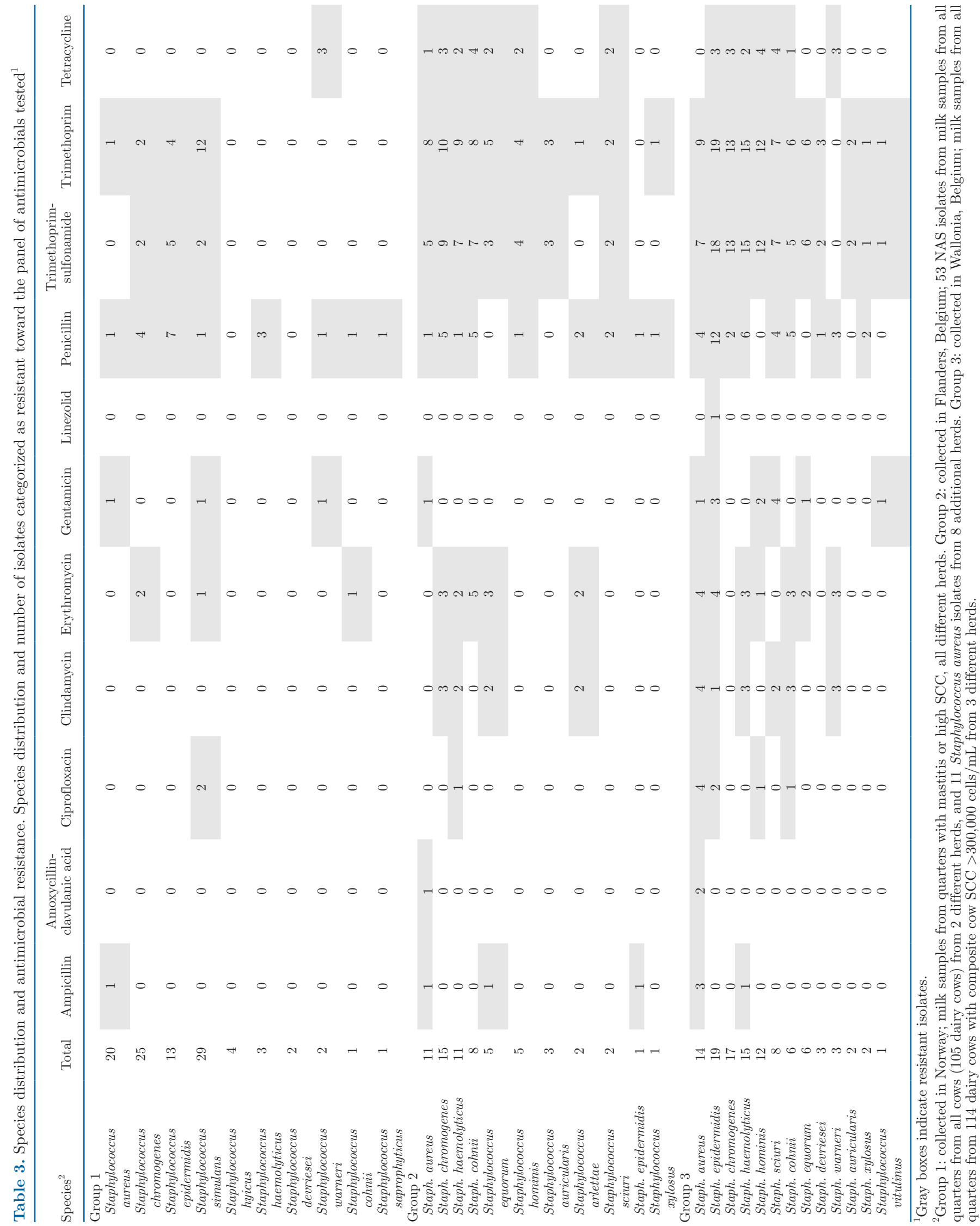


dis isolates showed resistance to cefoxitin. The Staph. haemolyticus isolate also showed resistance toward ampicillin, whereas the 4 others were susceptible, and all 5 NAS were phenotypically susceptible toward amoxicillin-clavulanic acid. These isolates also showed resistance toward 4 or fewer of the tested antimicrobials, including trimethoprim-sulfonamide $(4 / 5)$, penicillin $(2 / 5)$, gentamicin $(1 / 5)$, and ampicillin $(1 / 5)$.

Table 4 shows an overview of the resistance patterns of all Staph. aureus isolates.

\section{Virulence Factors}

The percentages of Staph. aureus isolates in each sample group harboring the different virulence genes are illustrated in Figure 4. All Staph. aureus isolates, except one with 2 virulence genes, carried at least 3 of the selected virulence genes. Table 5 shows the presence of virulence genes in a total of 8 NAS isolates.
Group 1. In group 1, $80 \%$ of Staph. aureus isolates carried at least 4 selected virulence genes. The cap5 gene was the least frequent gene, followed by the tsst01 and $f n b p B$ genes. One isolate carried 8 of the 9 examined virulence genes, lacking only cap5. Only one NAS isolate, a Staph. chromogenes isolate, carried any of the virulence genes, namely the tsst01 gene.

Group 2. A total of $73 \%$ of the Staph. aureus isolates in group 2 carried 5 or more of the selected virulence genes. The tsst01 and $f n b p B$ genes were the least frequent virulence genes; however, the tsst01 gene was also carried by the only NAS isolate from group 2 positive for any of the virulence genes tested. This was a Staph. chromogenes isolate.

Group 3. All Staph. aureus isolates carried 5 or more of the selected virulence genes, of which the tsst01 and $f n b p B$ genes were the least frequent. Three isolates from the same farm carried 7 virulence genes, missing the tsst01 and cap8 genes. In this group, 6 NAS iso-

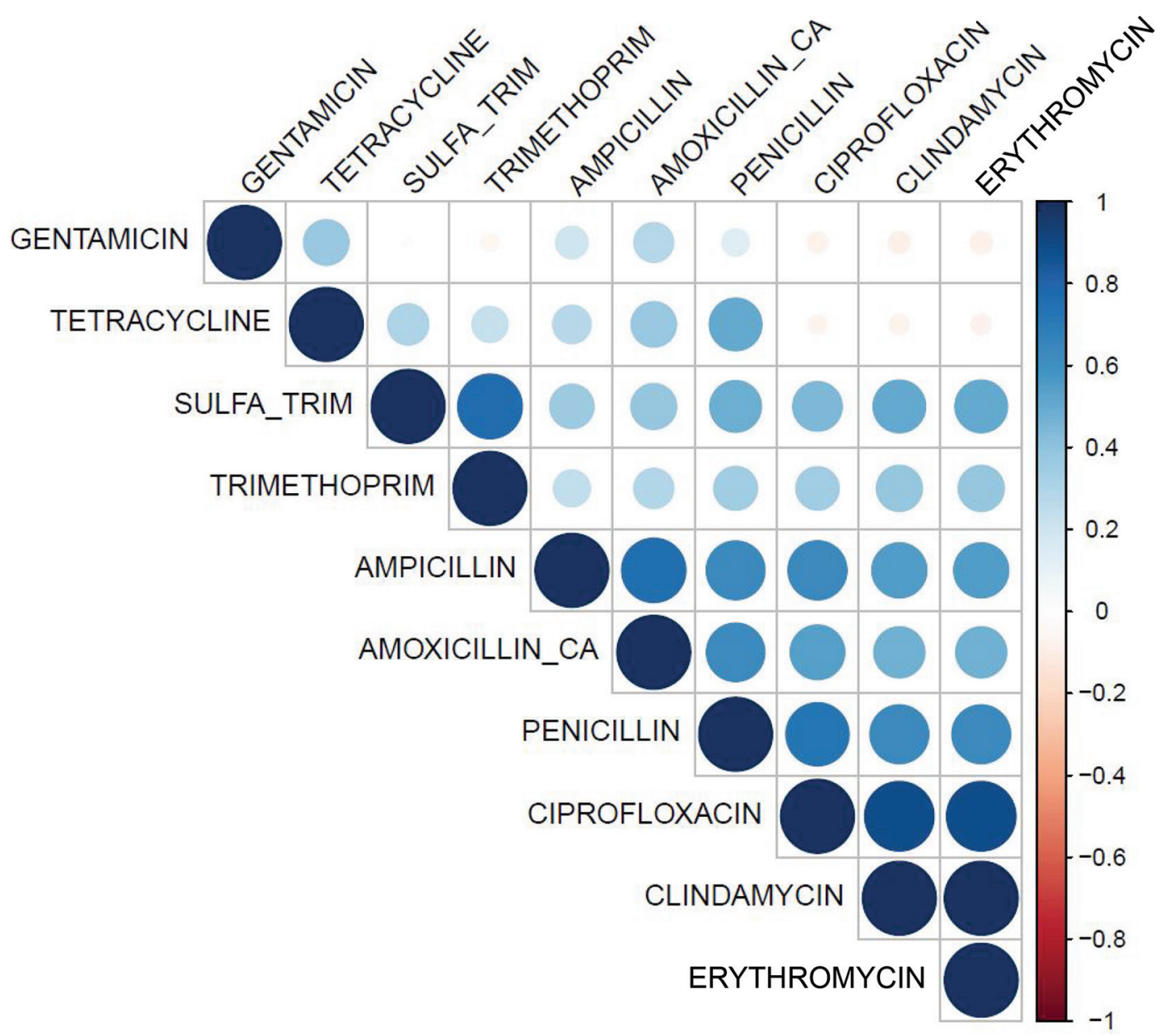

Figure 2. Correlation plot for observed antimicrobial resistances for Staphylococcus aureus isolates. Two variables with a phi coefficient $>0.7$ were considered to be strongly correlated. SULFA_TRIM = sulfonamide and trimethoprim; amoxicillin_ca = amoxicillin and clavulanic acid. 
lated carried 1,5 , or 6 of the selected virulence genes, although none with the same profile. This NAS group included 4 Staph. epidermidis isolates, 1 Staph. sciuri isolate, and 1 Staph. hominis isolate.

Figure 5 shows the correlation between the different virulence genes for Staph. aureus isolates. We detected little correlation between the virulence genes in Staph. aureus isolates. The least frequent virulence genes (tsst01 and $f n b p B)$ as well as the cap5 gene showed less correlation with other virulence genes. We found a negative correlation between the 2 cap genes, cap 5 and cap8, in Staph. aureus isolates.

\section{Resistance and Virulence}

The Staph. aureus isolate from group 1 with 8 virulence genes was completely susceptible toward the tested panel of antimicrobials. The 3 isolates from group 3 with 7 virulence genes were multidrug resis- tant, showing resistance toward 6 or more of the tested antimicrobials, and all 3 harbored the mecA gene. The remaining 2 mecA-positive Staph. aureus isolates carried 6 virulence genes and showed resistance toward 7 of the tested antimicrobials. Out of the 5 NAS that carried 1 virulence gene, one isolate was completely susceptible and the others showed resistance toward 1 to 3 of the tested antimicrobials. However, 1 of these isolates was a mecA-positive Staph. epidermidis. The other 4 mecA-positive NAS did not harbor any of the tested virulence genes. The NAS with 5 virulence genes showed resistance to 4 antimicrobials, and the 2 isolates with 6 virulence genes showed resistance toward 2 or 3 antimicrobials.

\section{DISCUSSION}

Methicillin-resistant Staph. aureus is a well-recognized and dreaded bacterium threatening both human

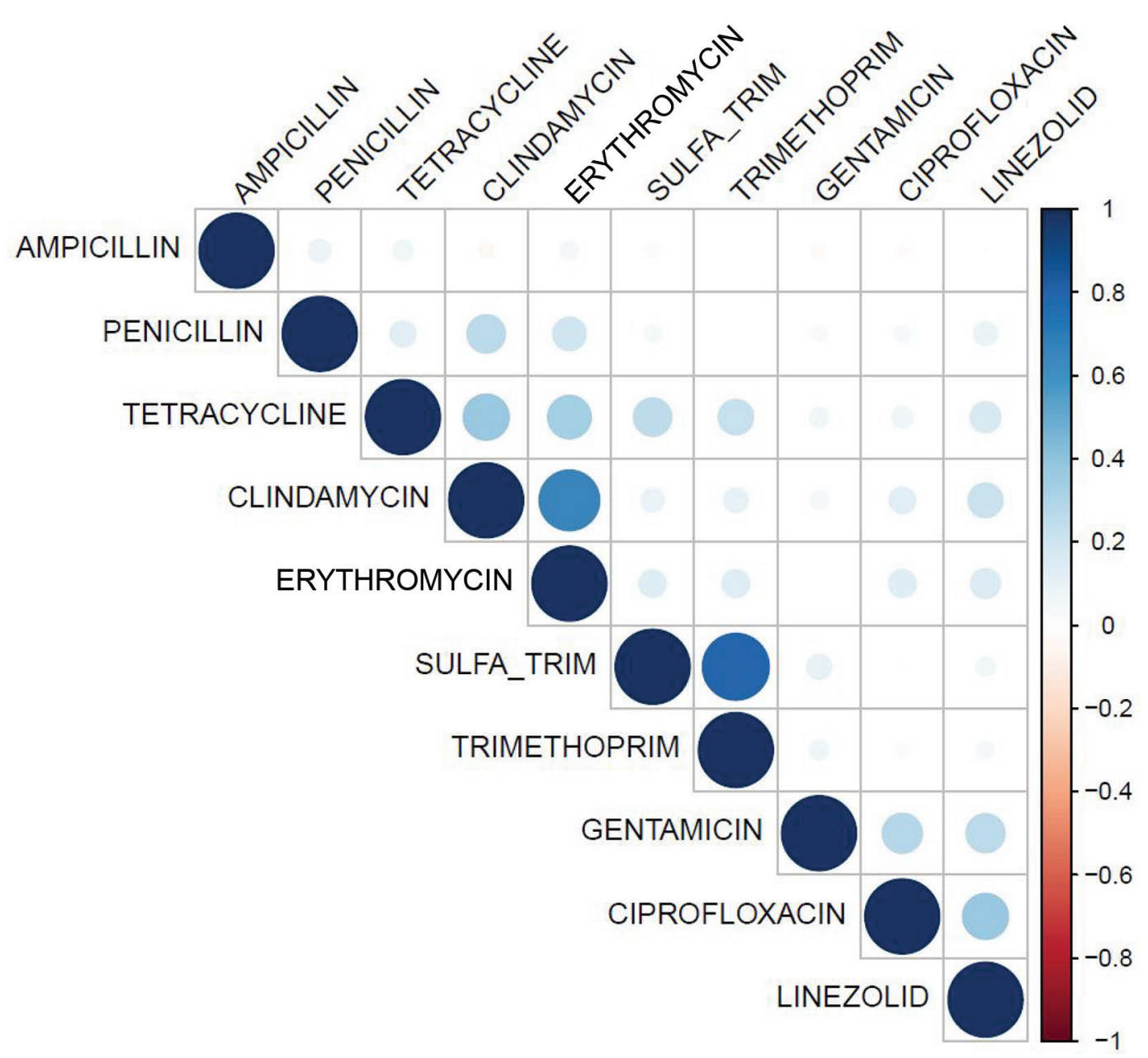

Figure 3. Correlation plot for observed antimicrobial resistances for NAS isolates. Two variables with a phi coefficient greater than 0.7 were considered to be strongly correlated. SULFA_TRIM = sulfonamide and trimethoprim. 


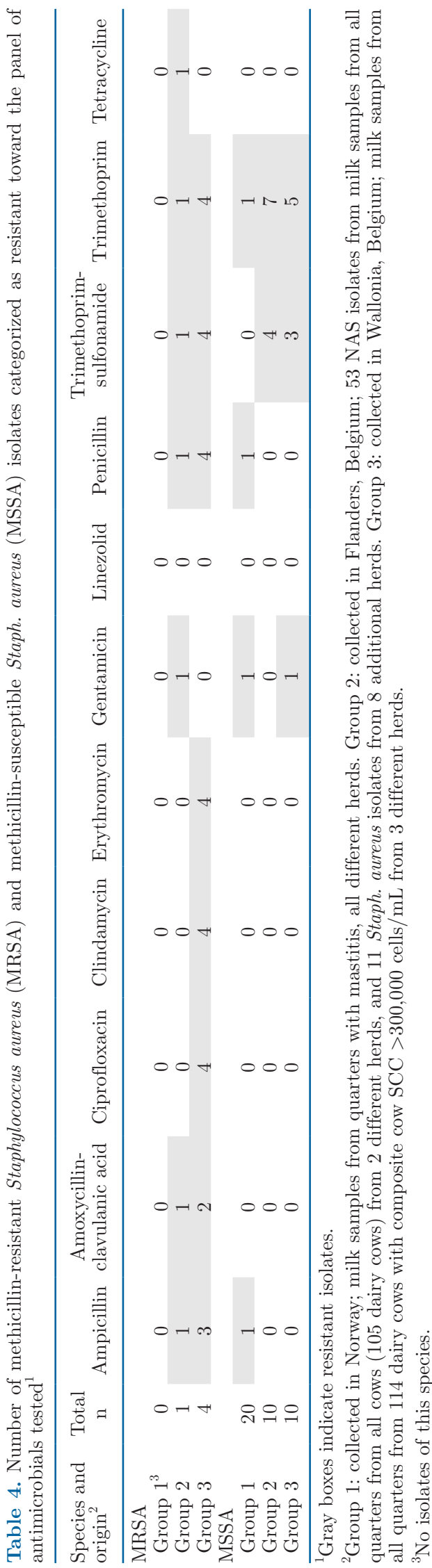

and animal health, causing potentially serious infections and limited treatment options. In addition, NAS are regarded as a potential reservoir for antimicrobial resistance genes that can be utilized by the more pathogenic Staph. aureus (Becker et al., 2014). This study provides findings of MRSA that are both multidrug resistant and harboring several virulence genes, and detection of several resistance traits in NAS isolates belonging to different species. By using 3 distinct collections of staphylococci from bovine milk samples of diverse origins, we were able once again to highlight the presence of antimicrobial resistance characteristics, as well as virulence genes, contributing to an increased knowledge base on this important bacterial group.

Descriptive analyses of antimicrobial resistance characteristics in all 3 sample groups showed that these were more widespread in several NAS species compared with Staph. aureus, apart from the MRSA isolates. This distribution corresponds with previous findings in Norwegian and Dutch surveillance systems for use of antimicrobial agents and occurrence of antimicrobial resistance (Mevius et al., 2007, 2008; NORM/NORMVET, 2015). Non-aureus staphylococci are believed to represent an important reservoir for antimicrobial resistance (Becker et al., 2014), and NAS isolates from group 2 and group 3 in this study were more frequently multidrug resistant compared with their group-corresponding Staph. aureus isolates. Antimicrobial resistance was frequently observed in Staph. epidermidis and Staph. haemolyticus regardless of sample group, the "worst case" being the one Staph. epidermidis isolate from group 3 that was resistant to 9 of the 11 tested antimicrobials and the only isolate phenotypically resistant to linezolid. However, this isolate was not mecA positive. The finding of multidrug-resistant Staph. epidermidis has been shown previously (Nobrega et al., 2018). Although the milk food chain is not regarded as a major transfer route for antimicrobial-resistant bacteria because the pasteurization process will kill vegetative bacteria, the fact that Staph. epidermidis and Staph. haemolyticus are common causes of nosocomial infections in humans (Spanu et al., 2003; Huang et al., 2005; Shin et al., 2011) suggests that resistant NAS from dairy cattle could potentially be a public health hazard.

The high prevalence of resistance toward trimethoprim and trimethoprim-sulfonamide in groups 2 and 3 was surprising. This contrasts with findings from other European studies on staphylococci, where resistance toward penicillin is most prevalent (Botrel et al., 2010; Persson Waller et al., 2011; Taponen et al., 2016). A survey conducted among 3,000 practitioners in 25 European countries reported that $\beta$-lactams, mainly penicillin, are the drugs of choice when treating bovine 


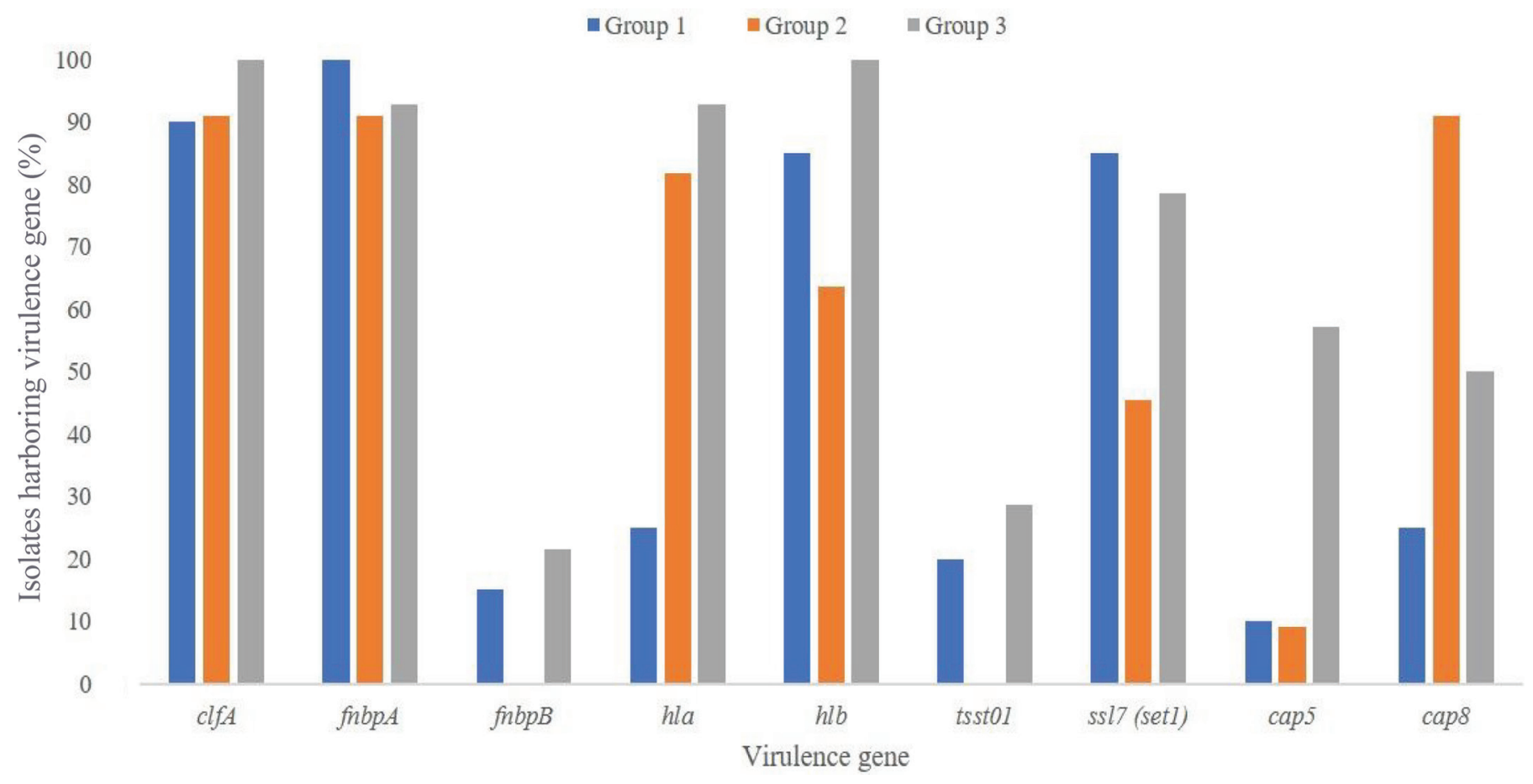

Figure 4. Percentage of Staphylococcus aureus isolates harboring the different virulence genes. Group 1: collected in Norway; milk samples from quarters with mastitis or high SCC, all different herds. Group 2: collected in Flanders, Belgium; 53 NAS isolates from milk samples from all quarters from all cows (105 dairy cows) from 2 different herds, and 11 Staph. aureus isolates from 8 additional herds. Group 3: collected in Wallonia, Belgium; milk samples from all quarters from 114 dairy cows with composite SCC >300,000 cells/mL from 3 different herds.

mastitis (De Briyne et al., 2014). In the European Surveillance of Veterinary Antimicrobial Consumption report of 2017 on sales of veterinary antimicrobial agents for food-producing animals, measured in milligrams per population-correction unit (mg/PCU), penicillin is the most sold drug in Norway and Belgium, followed by tetracyclines and sulfonamides in Belgium, and sulfonamides, amphenicols, and aminoglycosides in Norway

Table 5. Presence of virulence genes in single non-aureus staphylococcal isolates ${ }^{1}$

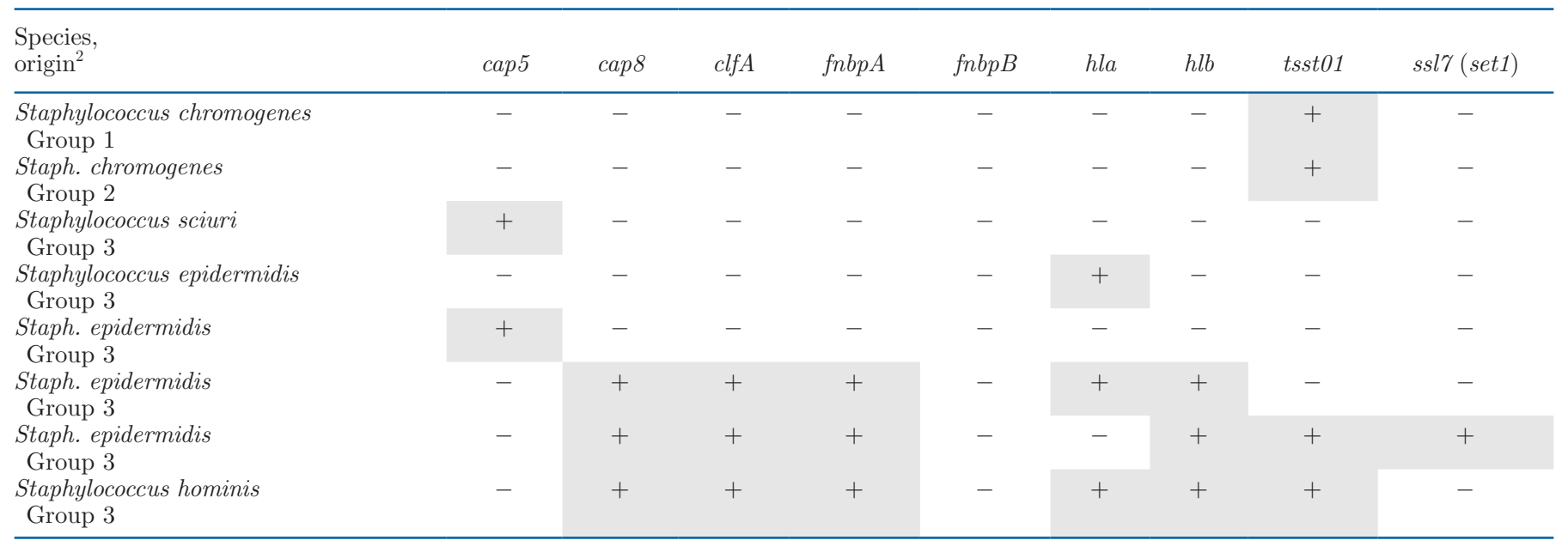

${ }^{1}$ Gray boxes indicate presence of virulence genes in individual isolates.

${ }^{2}$ Group 1: collected in Norway; milk samples from quarters with mastitis or high SCC, all different herds. Group 2: collected in Flanders, Belgium; 53 NAS isolates from milk samples from all quarters from all cows (105 dairy cows) from 2 different herds, and 11 Staphylococcus aureus isolates from 8 additional herds. Group 3: collected in Wallonia, Belgium; milk samples from all quarters from 114 dairy cows with composite cow $\mathrm{SCC}>300,000$ cells $/ \mathrm{mL}$ from 3 different herds. 
(European Medicines Agency, 2019), although the use of amphenicols in Norway is mostly related to farmed fish (Lillehaug et al., 2018). The survey from De Briyne et al. (2014) indicates that most practitioners report prescribing sulfonamides for pigs, not cattle. However, there is not always a simple link between the use of one antimicrobial and subsequent development of resistance toward the same antimicrobial. Studies of $E$. coli from horses and calves have shown that treatment with penicillin leads to increased phenotypic resistance to multiple unrelated antimicrobials (Grønvold et al., 2010; Grønvold et al., 2011). If similar, and still cryptic, relations between use and resistance also holds true for staphylococci, it may be one explanation of the high prevalence of observed trimethoprim and trimethoprimsulfonamide resistance. Resistance toward penicillin was most common in group 1, except in the Staph. simulans isolates, and second most common in groups 2 and 3, more in accordance with reported prescription patterns. Some of the observed differences in antimi- crobial resistance between group 1 and groups 2 and 3 might be related to differences between the countries, as Norway generally has a low prevalence of antimicrobial resistance in dairy herds (NORM/NORM-VET, 2017).

The strong correlation between erythromycin and clindamycin resistance observed in this study is consistent with what has been shown in other studies (Lüthje and Schwarz, 2006; Li et al., 2015). This is most likely due to $\mathrm{erm}$ genes that generally confer resistance toward both macrolides and lincosamides, as well as streptogramin B. These genes are commonly found in staphylococci and are often located on mobile genetic elements, which could allow for horizontal spread of the genes (Feßler et al., 2018). It is interesting to note that stronger correlations seem to exist between the observed resistances in the Staph. aureus isolates compared with the NAS isolates. This could possibly be related to the plasticity of the Staph. aureus pan genome, with mobile elements readily exchanged between Staph. aureus isolates, and resistance genes possibly

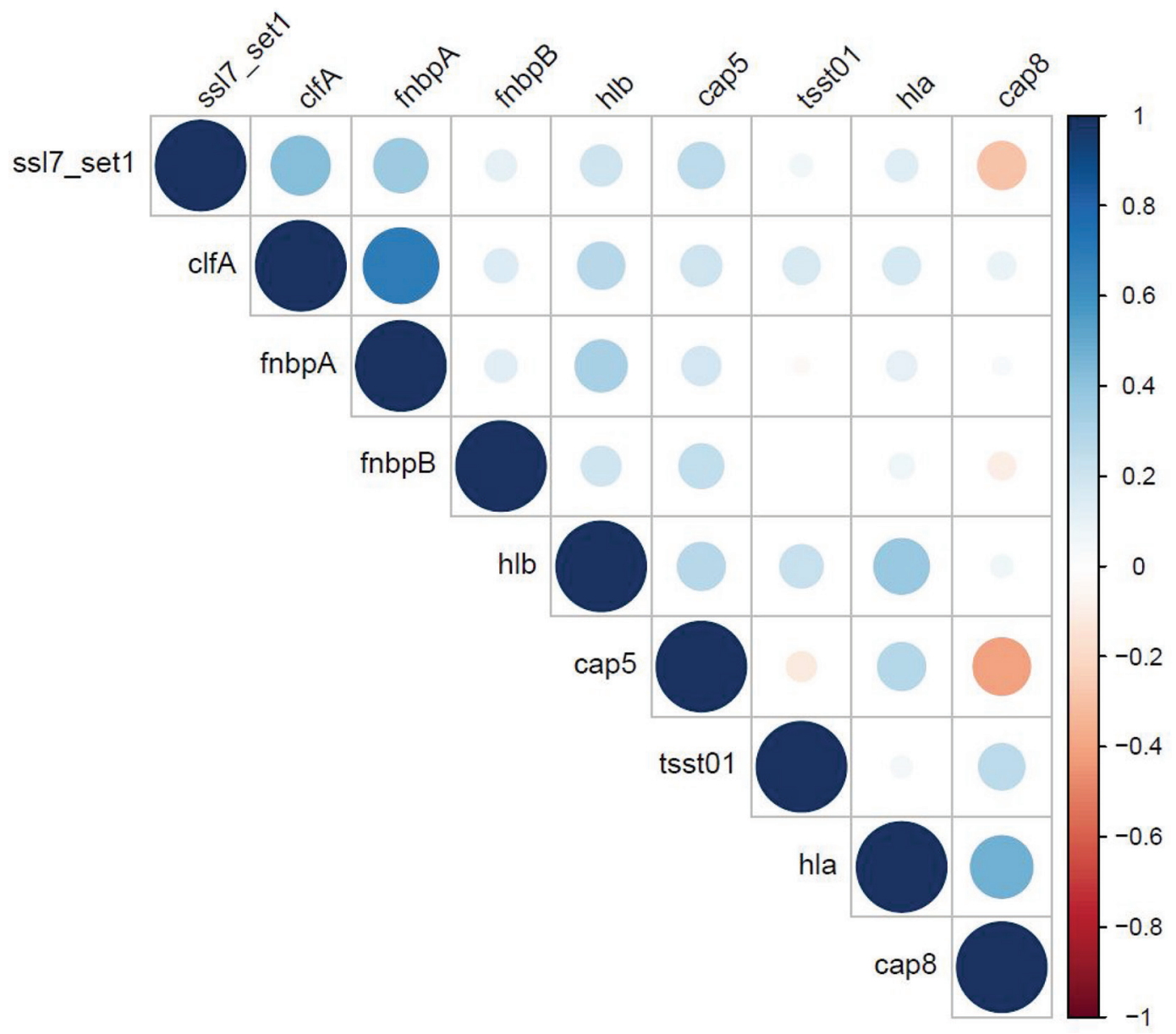

Figure 5. Correlation plot of virulence genes for Staphylococcus aureus isolates. Two variables with a phi coefficient $>0.7$ were considered to be strongly correlated. 
co-localized on these mobile elements (Holden et al., 2004; Lindsay and Holden, 2004). Because this study mostly tested phenotypic resistance, it is also possible that some isolates carry resistance mechanisms conferring resistance to multiple antimicrobial classes (Wendlandt et al., 2015). Although one may assume that these genes and elements spread between staphylococcal species, it is possible that the more pathogenic Staph. aureus is more often exposed to antimicrobial treatments and therefore more frequently exchanges mobile elements containing resistance genes. However, because NAS are often found as commensals, it could be expected that these staphylococci are constantly exposed to systemically administered antimicrobial agents; this has also been proposed in another study (Stevens et al., 2018). This assumption may contribute to explain the development of NAS as a reservoir for antimicrobial resistance.

A previous study of Belgian farms suffering from Staph. aureus mastitis indicated that about $10 \%$ of these Staph. aureus isolates were MRSA (Vanderhaeghen et al., 2010). As documented, MRSA strains display resistance to a variety of antimicrobial agents, in addition to their resistance to $\beta$-lactams (Vanderhaeghen et al., 2010; Bardiau et al., 2013). Our results are consistent with these observations, as the 5 MRSA showed resistance to 6 to 8 of the tested antimicrobials. The high prevalence of antimicrobial resistance in MRSA is a serious problem, limiting treatment options and threatening both animal and human health.

The 5 MRSA isolates were concordantly resistant to cefoxitin on disk diffusion, yet only 2 of the mecApositive NAS showed this resistance. The possibility exists that these NAS isolates may carry a variant of the $m e c A$ gene that does not confer resistance to cefoxitin. Studies regarding the evolution of mecA and the mobile genetic cassette that carries the gene in staphylococci have found that most Staph. sciuri harbor a gene, mecA1, with $80 \%$ homology to mecA in Staph. aureus. However, this gene generally does not confer methicillin resistance (Couto et al., 1996; Wu et al., 1996). It is also possible that the mecA gene is truncated or not expressed in these isolates. In addition, 15 NAS isolates were phenotypically resistant to cefoxitin without a positive PCR for the mecA gene. The explanation of why some of the NAS isolates did not show phenotypic cefoxitin resistance despite harboring a $m e c A$ gene and others showed resistance without being $m e c A$-positive on PCR is not known at this stage and warrants further genetic studies. For example, some reports have found a plasmid-encoded $m e c B$ gene in Staph. aureus isolates, which, if present in the cefoxitin-resistant NAS, could explain the negative PCR for mecA and mecC (Becker et al., 2018).
We found a high prevalence of several virulence genes in Staph. aureus in all groups, especially $c l f A, f n b p A$, and $h l b$, as well as a low occurrence of $f n b p B$. These patterns are in accordance with other studies of both bovine and human Staph. aureus isolates (Booth et al., 2001; Salasia et al., 2004). We observed a higher frequency of hlb compared with hla in both groups of staphylococci collected from cows with mastitis or high cow SCC (groups 1 and 3). This contrasts with findings from clinical human isolates, were hla appears more common (Booth et al., 2001). However, Aarestrup et al. (1999) found the $h l b$ gene to be significantly more prevalent in bovine isolates compared with human isolates. This indicates that $h l b$ might play a more important role in the pathogenicity of Staph. aureus in bovine mastitis, which is also proposed in another study (Resch et al., 2013). We detected a strong correlation between several different virulence genes, especially ssl' (set 1 ), $h l b, c l f A$, and $f n b p A$, further indicating that these genes are important determinants in the virulence of Staph. aureus associated with the bovine udder. Adherence to extracellular matrix proteins is believed to be crucial for the ability of Staph. aureus to colonize and invade tissue (Cremonesi et al., 2013). Fibronectin-binding proteins play a significant role in bacterial adhesion and invasion of the bovine mammary gland (Lammers et al., 1999), and the clfA and clfB genes are also associated with the initial adherence of Staph. aureus to the teat canal (da Costa et al., 2014). This makes Staph. aureus harboring clf $A$ and $f n b p B$ especially fit for invasion (Cremonesi et al., 2013). The ssly (set1) gene represents a group of genes encoding staphylococcal superantigen-like proteins that shares homology with other superantigens (Langley et al., 2005). The gene encodes a protein that contributes to bacterial immune evasion, such as inhibition of phagocytosis and cytokine and chemokine secretion (Wines et al., 2011). The role of superantigens and superantigen-like proteins in the pathogenesis of bovine mastitis is not fully known. However, indications exist that these proteins play a role in bovine mastitis, inducing tissue damage and inflammation, as well as immunosuppression and immune evasion (Wilson et al., 2018). This study further supports the virulence potential of Staph. aureus, with many of the isolates carrying several virulence genes. It is worth noting that the 5 mecA-positive Staph. aureus isolates harbored 7 or 8 of the screened virulence genes, in addition to showing phenotypic resistance toward 6 or more of the tested antimicrobials. These isolates pose serious challenges for the management of individual udder infections, as the bacteria have a high pathogenic potential and are difficult to treat.

The screened virulence genes were derived from studies on Staph. aureus, potentially leading to a lower de- 
tection of these genes in NAS species. Compared with Staph. aureus, less is known about the pathogenicity of NAS, but they possess fewer virulence properties than Staph. aureus (Becker et al., 2014). In more recent studies, virulence genes in NAS have been identified by whole-genome sequencing of different collections of isolates (Âvall-Jääskeläinen et al., 2018; Naushad et al., 2019), but no conclusive findings about gene content and virulence have been made.

The isolates in this study were collected from dairy farms in Norway and 2 regions (Flanders and Wallonia) in Belgium, but, as the sampling regimens were different for the 3 geographical areas, the results are not comparable between regions. The main reasons for the variability in sampling strategies were the different structures of the dairy farm industry in Norway versus Belgium, and the accessibility to farms. These differences in sampling strategies might have affected the distribution of NAS species in the different groups. In group 1, NAS species were isolated from samples primarily sent to the laboratory due to high SCC or clinical mastitis, whereas in groups 2 and 3 NAS were collected from samples from all quarters of each animal. This could explain why Staph. simulans was more frequently isolated in group 1 and Staph. cohnii more prevalent in groups 2 and 3, as Staph. simulans has been shown to be associated with a higher SCC compared with several other NAS species and Staph. cohnii more frequently associated with low SCC (Supré et al., 2011; Condas et al., 2017). There is also a possibility that isolates collected from different cows in groups 2 and 3 are part of the same strain, so-called copy strains, as Staph. aureus is considered a contagious pathogen (Kirkeby et al., 2019) transmitted from cow to cow.

\section{CONCLUSIONS}

By using 3 distinct collections of staphylococci from bovine milk samples of diverse origins, we were able once again to highlight the presence of antimicrobial resistance characteristics, as well as virulence genes, contributing to an increased knowledge base of this important bacterial group. Antimicrobial resistance characteristics in all 3 sample groups were more widespread in several NAS species compared with Staph. aureus, apart from the MRSA isolates. In all groups, antimicrobial resistance was common in Staph. epidermidis and Staph. haemolyticus. Only a few NAS isolates carried any of the virulence genes typically displayed by Staph. aureus. Even though the results for the MRSA in this study are concerning with regard to multidrug resistance, most of the Staph. aureus collected did not carry the mecA gene and showed relatively little resis- tance, giving hope that it is still possible to slow the development and spread of MRSA among dairy cattle.

\section{ACKNOWLEDGMENTS}

This project was part of the ERA-Net Animal Health and Welfare (ANIHWA), MRSA_bacteriophages project. The project was funded by the Research Council of Norway, the Research Foundation - Flanders (FWO), and Service Public Fédéral - Santé publique, Sécurité de la Chaîne alimentaire et Environnement (Wallonia). Salary was provided by each home institution. We thank Ola B. Brynildsrud (Norwegian Institute of Public Health, Norway) for assistance with correlation plots. We are very grateful for the laboratory help from Olga Anna Osinska (Department of Paraclinical Sciences, Faculty of Veterinary Medicine, Norwegian University of Life Sciences, currently Norwegian Institute of Public Health, Norway). We thank Olav Østerås (Dairy Advisory Services, TINE SA, Norway) for valuable input to the manuscript. We thank Anne-Sophie Rao (Department of Farm Animal Clinics, Faculty of Veterinary Medicine, University of Liège, Belgium) and the MammiScan project (SPW-DGARNE) for the milk sampling in Wallonia. The authors have not stated any conflicts of interest.

\section{REFERENCES}

Aarestrup, F. M., H. D. Larsen, N. H. Eriksen, C. S. Elsberg, and N. E. Jensen. 1999. Frequency of $\alpha$ - and $\beta$-haemolysin in Staphylococcus aureus of bovine and human origin. A comparison between pheno- and genotype and variation in phenotypic expression. APMIS 107:425-430. https://doi.org/10.1111/j.1699-0463.1999.tb01576.x.

Åvall-Jääskeläinen, S., S. Taponen, R. Kant, L. Paulin, J. Blom, A. Palva, and J. Koort. 2018. Comparative genome analysis of 24 bovine-associated Staphylococcus isolates with special focus on the putative virulence genes. PeerJ 6:e4560. https://doi.org/10.7717/ peerj. 4560.

Bardiau, M., K. Yamazaki, J. N. Duprez, B. Taminiau, J. G. Mainil, and I. Ote. 2013. Genotypic and phenotypic characterization of methicillin-resistant Staphylococcus aureus (MRSA) isolated from milk of bovine mastitis. Lett. Appl. Microbiol. 57:181-186. https:/ /doi.org/10.1111/lam.12099.

Bauer, A. W., W. M. Kirby, J. C. Sherris, and M. Turck. 1966. Antibiotic susceptibility testing by a standardized single disk method. Am. J. Clin. Pathol. 45:493-496.

Becker, K., C. Heilmann, and G. Peters. 2014. Coagulase-negative staphylococci. Clin. Microbiol. Rev. 27:870-926. https://doi.org/ 10.1128/CMR.00109-13.

Becker, K., S. van Alen, E. A. Idelevich, N. Schleimer, J. Seggewiß, A. Mellmann, U. Kaspar, and G. Peters. 2018. Plasmid-encoded transferable mecB-mediated methicillin resistance in Staphylococcus aureus. Emerg. Infect. Dis. 24:242-248. https://doi.org/10 .3201/eid2402.171074.

Booth, M. C., L. M. Pence, P. Mahasreshti, M. C. Callegan, and M. S. Gilmore. 2001. Clonal associations among Staphylococcus aureus isolates from various sites of infection. Infect. Immun. 69:345-352. https://doi.org/10.1128/IAI.69.1.345-352.2001.

Botrel, M. A., M. Haenni, E. Morignat, P. Sulpice, J. Y. Madec, and D. Calavas. 2010. Distribution and antimicrobial resistance of 
clinical and subclinical mastitis pathogens in dairy cows in RhôneAlpes, France. Foodborne Pathog. Dis. 7:479-487. https://doi.org/ 10.1089/fpd.2009.0425.

Cameron, M., H. W. Barkema, J. De Buck, S. De Vliegher, M. Chaffer, J. Lewis, and G. P. Keefe. 2017. Identification of bovine-associated coagulase-negative staphylococci by matrix-assisted laser desorption/ionization time-of-flight mass spectrometry using a direct transfer protocol. J. Dairy Sci. 100:2137-2147. https://doi.org/10 .3168/jds.2016-12020.

Cameron, M., J. Perry, J. R. Middleton, M. Chaffer, J. Lewis, and G. P. Keefe. 2018. Short communication: Evaluation of MALDI-TOF mass spectrometry and a custom reference spectra expanded database for the identification of bovine-associated coagulase-negative staphylococci. J. Dairy Sci. 101:590-595. https://doi.org/10.3168/ jds.2017-13226.

Condas, L. A. Z., J. De Buck, D. B. Nobrega, D. A. Carson, J. P. Roy, G. P. Keefe, T. J. DeVries, J. R. Middleton, S. Dufour, and H. W. Barkema. 2017. Distribution of non-aureus staphylococci species in udder quarters with low and high somatic cell count, and clinical mastitis. J. Dairy Sci. 100:5613-5627. https://doi.org/10.3168/jds 2016-12479.

Couto, I., H. de Lencastre, E. Severina, W. Kloos, J. A. Webster, R. J. Hubner, I. S. Sanches, and A. Tomasz. 1996. Ubiquitous presence of a mecA homologue in natural isolates of Staphylococcus sciuri. Microb. Drug Resist. 2:377-391. https://doi.org/10.1089/ mdr.1996.2.377.

Cremonesi, P., T. Zottola, C. Locatelli, C. Pollera, B. Castiglioni, L. Scaccabarozzi, and P. Moroni. 2013. Identification of virulence factors in 16S-23S rRNA intergenic spacer genotyped Staphylococcus aureus isolated from water buffaloes and small ruminants. J. Dairy Sci. 96:7666-7674. https://doi.org/10.3168/jds.2013-6917.

da Costa, L. B., P. J. Rajala-Schultz, A. Hoet, K. S. Seo, K. Fogt, and B. S. Moon. 2014. Genetic relatedness and virulence factors of bovine Staphylococcus aureus isolated from teat skin and milk. J. Dairy Sci. 97:6907-6916. https://doi.org/10.3168/jds.2014-7972.

Dalen, G., A. Rachah, H. Nørstebø, Y. H. Schukken, and O. Reksen. 2019. The detection of intramammary infections using online somatic cell counts. J. Dairy Sci. 102:5419-5429. https://doi.org/10 $.3168 /$ jds.2018-15295.

De Briyne, N., J. Atkinson, S. P. Borriello, and L. Pokludová. 2014. Antibiotics used most commonly to treat animals in Europe. Vet. Rec. 175:325. https://doi.org/10.1136/vr.102462.

De Visscher, A., F. Haesebrouck, S. Piepers, W. Vanderhaeghen, K. Supré, F. Leroy, E. Van Coillie, and S. De Vliegher. 2013. Assessment of the suitability of mannitol salt agar for growing bovineassociated coagulase-negative staphylococci and its use under field conditions. Res. Vet. Sci. 95:347-351. https://doi.org/10.1016/j .rvsc.2013.05.015.

De Visscher, A., S. Piepers, F. Haesebrouck, and S. De Vliegher. 2016. Intramammary infection with coagulase-negative staphylococci at parturition: Species-specific prevalence, risk factors, and effect on udder health. J. Dairy Sci. 99:6457-6469. https://doi.org/10.3168/ jds.2015-10458.

De Vliegher, S., L. K. Fox, S. Piepers, S. McDougall, and H. W. Barkema. 2012. Invited review: Mastitis in dairy heifers: Nature of the disease, potential impact, prevention, and control. J. Dairy Sci. 95:1025-1040. https://doi.org/10.3168/jds.2010-4074.

El Garch, F., M. Youala, S. Simjee, H. Moyaert, R. Klee, B. Truszkowska, M. Rose, D. Hocquet, B. Valot, I. Morrissey, and A. de Jong. 2020. Antimicrobial susceptibility of nine udder pathogens recovered from bovine clinical mastitis milk in Europe 2015-2016: VetPath results. Vet. Microbiol. 245:108644. https://doi.org/10 .1016/j.vetmic.2020.108644.

European Medicines Agency. 2019. Sales of veterinary antimicrobial agents in 31 European countries in 2017. European Surveillance of Veterinary Antimicrobial Consumption. Accessed Apr. 15, 2021. https://www.ema.europa.eu/en/documents/report/ sales-veterinary-antimicrobial-agents-31-european-countries-2018 -trends-2010-2018-tenth-esvac-report_en.pdf.

Feßler, A. T., C. Billerbeck, K. Kadlec, and S. Schwarz. 2010. Identification and characterization of methicillin-resistant coagulase- negative staphylococci from bovine mastitis. J. Antimicrob. Chemother. 65:1576-1582. https://doi.org/10.1093/jac/dkq172.

Feßler, A. T., Y. Wang, C. Wu, and S. Schwarz. 2018. Mobile lincosamide resistance genes in staphylococci. Plasmid 99:22-31. https:/ /doi.org/10.1016/j.plasmid.2018.06.002.

Gao, J., H. W. Barkema, L. Zhang, G. Liu, Z. Deng, L. Cai, R. Shan, S. Zhang, J. Zou, J. P. Kastelic, and B. Han. 2017. Incidence of clinical mastitis and distribution of pathogens on large Chinese dairy farms. J. Dairy Sci. 100:4797-4806. https://doi.org/10.3168/ jds.2016-12334.

Gindonis, V., S. Taponen, A. L. Myllyniemi, S. Pyörälä, S. Nykäsenoja, S. Salmenlinna, L. Lindholm, and M. Rantala. 2013. Occurrence and characterization of methicillin-resistant staphylococci from bovine mastitis milk samples in Finland. Acta Vet. Scand. 55:61. https://doi.org/10.1186/1751-0147-55-61.

Grønvold, A. M., T. M. L'Abée-Lund, E. Strand, H. Sørum, A. C. Yannarell, and R. I. Mackie. 2010. Fecal microbiota of horses in the clinical setting: Potential effects of penicillin and general anesthesia. Vet. Microbiol. 145:366-372. https://doi.org/10.1016/j .vetmic.2010.03.023.

Grønvold, A. M., Y. Mao, T. M. L'Abée-Lund, H. Sørum, T. Sivertsen, A. C. Yannarell, and R. I. Mackie. 2011. Fecal microbiota of calves in the clinical setting: Effect of penicillin treatment. Vet. Microbiol. 153:354-360. https://doi.org/10.1016/j.vetmic.2011.05.040.

Halasa, T., K. Huijps, O. Østerås, and H. Hogeveen. 2007. Economic effects of bovine mastitis and mastitis management: A review. Vet. Q. 29:18-31. https://doi.org/10.1080/01652176.2007.9695224.

Hanssen, A. M., and J. U. Ericson Sollid. 2006. SCCmec in staphylococci: Genes on the move. FEMS Immunol. Med. Microbiol. 46:820. https://doi.org/10.1111/j.1574-695X.2005.00009.x.

Heikkilä, A. M., E. Liski, S. Pyörälä, and S. Taponen. 2018. Pathogen-specific production losses in bovine mastitis. J. Dairy Sci. 101:9493-9504. https://doi.org/10.3168/jds.2018-14824.

Holden, M. T., E. J. Feil, J. A. Lindsay, S. J. Peacock, N. P. Day, M. C. Enright, T. J. Foster, C. E. Moore, L. Hurst, R. Atkin, A. Barron, N. Bason, S. D. Bentley, C. Chillingworth, T. Chillingworth, C. Churcher, L. Clark, C. Corton, A. Cronin, J. Doggett, L. Dowd, T. Feltwell, Z. Hance, B. Harris, H. Hauser, S. Holroyd, K. Jagels, K. D. James, N. Lennard, A. Line, R. Mayes, S. Moule, K. Mungall, D. Ormond, M. A. Quail, E. Rabbinowitsch, K. Rutherford, M. Sanders, S. Sharp, M. Simmonds, K. Stevens, S. Whitehead, B. G. Barrell, B. G. Spratt, and J. Parkhill. 2004. Complete genomes of two clinical Staphylococcus aureus strains: Evidence for the rapid evolution of virulence and drug resistance. Proc. Natl. Acad. Sci. USA 101:9786-9791. https://doi.org/10.1073/pnas.0402521101.

Huang, C. R., C. H. Lu, J. J. Wu, H. W. Chang, C. C. Chien, C. B. Lei, and W. N. Chang. 2005. Coagulase-negative staphylococcal meningitis in adults: Clinical characteristics and therapeutic outcomes. Infection 33:56-60. https://doi.org/10.1007/s15010-005 $-4083-7$.

Kadlec, K., A. T. Fessler, T. Hauschild, and S. Schwarz. 2012. Novel and uncommon antimicrobial resistance genes in livestock-associated methicillin-resistant Staphylococcus aureus. Clin. Microbiol. Infect. 18:745-755. https://doi.org/10.1111/j.1469-0691.2012 $.03842 . \mathrm{x}$.

Kirkeby, C., L. Zervens, N. Toft, D. Schwarz, M. Farre, S. Hechinger, and T. Halasa. 2019. Transmission dynamics of Staphylococcus aureus within two Danish dairy cattle herds. J. Dairy Sci. 102:14281442. https://doi.org/10.3168/jds.2018-15106.

Lammers, A., P. J. Nuijten, and H. E. Smith. 1999. The fibronectin binding proteins of Staphylococcus aureus are required for adhesion to and invasion of bovine mammary gland cells. FEMS Microbiol. Lett. 180:103-109. https://doi.org/10.1111/j.1574-6968.1999 .tb08783.x.

Langley, R., B. Wines, N. Willoughby, I. Basu, T. Proft, and J. D. Fraser. 2005. The staphylococcal superantigen-like protein 7 binds IgA and complement C5 and inhibits IgA-Fc alpha RI binding and serum killing of bacteria. J. Immunol. 174:2926-2933. https://doi .org/10.4049/jimmunol.174.5.2926.

Lee, J. H. 2003. Methicillin (oxacillin)-resistant Staphylococcus aureus strains isolated from major food animals and their potential trans- 
mission to humans. Appl. Environ. Microbiol. 69:6489-6494. https: //doi.org/10.1128/AEM.69.11.6489-6494.2003.

Levy, S. B., and B. Marshall. 2004. Antibacterial resistance worldwide: Causes, challenges and responses. Nat. Med. 10(Suppl. 12):S122S129. https://doi.org/10.1038/nm1145.

Li, L., W. Feng, Z. Zhang, H. Xue, and X. Zhao. 2015. Macrolidelincosamide-streptogramin resistance phenotypes and genotypes of coagulase-positive Staphylococcus aureus and coagulase-negative staphylococcal isolates from bovine mastitis. BMC Vet. Res. 11:168. https://doi.org/10.1186/s12917-015-0492-8.

Lillehaug, A., C. Børnes, and K. Grave. 2018. A pharmaco-epidemiological study of antibacterial treatments and bacterial diseases in Norwegian aquaculture from 2011 to 2016. Dis. Aquat. Organ. 128:117-125. https://doi.org/10.3354/dao03219.

Lindsay, J. A., and M. T. Holden. 2004. Staphylococcus aureus: Superbug, super genome? Trends Microbiol. 12:378-385. https://doi .org/10.1016/j.tim.2004.06.004.

Lüthje, P., and S. Schwarz. 2006. Antimicrobial resistance of coagulasenegative staphylococci from bovine subclinical mastitis with particular reference to macrolide-lincosamide resistance phenotypes and genotypes. J. Antimicrob. Chemother. 57:966-969. https://doi $.0 r g / 10.1093 / \mathrm{jac} / \mathrm{dkl} 1061$.

Mevius, D., M. G. J. Koene, L. F. Puister, R. H. M. Bergevoet, H. B. van der Veen, and I. van Geijlswijk. MARAN 2008: Monitoring of antimicrobial resistance and antibiotic usage in animals in the Netherlands in 2008. Accessed Apr. 8, 2021. https://www.wur .nl/upload_mm/7/6/a/5becb8c3-70be-4930-ae2f-397760c2b440 _MARAN2008.pdf.

Mevius, D., B. Wit, W. Van Pelt, L. F. Puister-Jansen, N. Bondt, R. H. M. Bergevoet, and I. M. Van Geijlswijk. MARAN 2007: Monitoring of antimicrobial resistance and antibiotic usage in animals in the Netherlands in 2006/2007. Accessed Apr. 8, 2021. https: //www.wur.nl/upload_mm/a/7/3/049cc3d3-86d8-4352-a889 -539c97849628_MARAN2006-2007.pdf.

Mikalsen, V., O. Østerås, and T. Roalkvam. 2019. Statistics collection: Statistikksamling fra Ku- og Geitekontrollen 2019. Husdyrkontrollen, TINE Rådgivning, Norway. Accessed Apr. 15, 2021. https:/ /www.geno.no/contentassets/f2a65a5153e04bf299653d9fde0c1151/ statistikksamling-2019-ku-og-geitekontrollen.pdf.

Naushad, S., S. A. Naqvi, D. Nobrega, C. Luby, J. P. Kastelic, H. W. Barkema, and J. De Buck. 2019. Comprehensive virulence gene profiling of bovine non-aureus staphylococci based on whole-genome sequencing data. mSystems 4:e00098-18. https://doi.org/10 $.1128 /$ mSystems.00098-18.

Nobrega, D. B., J. De Buck, and H. W. Barkema. 2018. Antimicrobial resistance in non-aureus staphylococci isolated from milk is associated with systemic but not intramammary administration of antimicrobials in dairy cattle. J. Dairy Sci. 101:7425-7436. https:/ /doi.org/10.3168/jds.2018-14540.

Nobrega, D. B., J. De Buck, S. A. Naqvi, G. Liu, S. Naushad, V. Saini, and H. W. Barkema. 2017. Comparison of treatment records and inventory of empty drug containers to quantify antimicrobial usage in dairy herds. J. Dairy Sci. 100:9736-9745. https://doi.org/10 $.3168 /$ jds.2017-13116.

NORM/NORM-VET. 2015. Usage of antimicrobial agents and occurrence of antimicrobial resistance in Norway. Troms $\varnothing /$ Oslo 2016. Accessed Apr. 8, 2021. https://www.vetinst.no/en/surveillance -programmes/norm-norm-vet-report.

NORM/NORM-VET. 2017. Usage of antimicrobial agents and occurrence of antimicrobial resistance in Norway Troms $\varnothing /$ Oslo 2018. Accessed Apr. 8, 2021. https://www.vetinst.no/en/surveillance -programmes/norm-norm-vet-report.

Olde Riekerink, R. G., H. W. Barkema, D. F. Kelton, and D. T. Scholl. 2008. Incidence rate of clinical mastitis on Canadian dairy farms. J. Dairy Sci. 91:1366-1377. https://doi.org/10.3168/jds.2007-0757.

Oliver, S. P., and S. E. Murinda. 2012. Antimicrobial resistance of mastitis pathogens. Vet. Clin. North Am. Food Anim. Pract. 28:165-185. https://doi.org/10.1016/j.cvfa.2012.03.005.

Østerås, O., L. Sølverød, and O. Reksen. 2006. Milk culture results in a large Norwegian survey-Effects of season, parity, days in milk, resistance, and clustering. J. Dairy Sci. 89:1010-1023. https://doi .org/10.3168/jds.S0022-0302(06)72167-1.

Ote, I., B. Taminiau, J. N. Duprez, I. Dizier, and J. G. Mainil. 2011. Genotypic characterization by polymerase chain reaction of Staphylococcus aureus isolates associated with bovine mastitis. Vet. Microbiol. 153:285-292. https://doi.org/10.1016/j.vetmic.2011.05 .042 .

Persson Waller, K., A. Aspán, A. Nyman, Y. Persson, and U. Grönlund Andersson. 2011. CNS species and antimicrobial resistance in clinical and subclinical bovine mastitis. Vet. Microbiol. 152:112116. https://doi.org/10.1016/j.vetmic.2011.04.006.

Piepers, S., L. De Meulemeester, A. de Kruif, G. Opsomer, H. W. Barkema, and S. De Vliegher. 2007. Prevalence and distribution of mastitis pathogens in subclinically infected dairy cows in Flanders, Belgium. J. Dairy Res. 74:478-483. https://doi.org/10.1017/ S0022029907002841.

R Core Team. 2013. R: A language and environment for statistical computing. R Foundation for Statistical Computing.

Resch, G., P. François, D. Morisset, M. Stojanov, E. J. Bonetti, J. Schrenzel, O. Sakwinska, and P. Moreillon. 2013. Human-to-bovine jump of Staphylococcus aureus CC8 is associated with the loss of a $\beta$-hemolysin converting prophage and the acquisition of a new staphylococcal cassette chromosome. PLoS One 8:e58187. https:// doi.org/10.1371/journal.pone.0058187.

Rollin, E., K. C. Dhuyvetter, and M. W. Overton. 2015. The cost of clinical mastitis in the first 30 days of lactation: An economic modeling tool. Prev. Vet. Med. 122:257-264. https://doi.org/10.1016/j .prevetmed.2015.11.006.

Saini, V., J. T. McClure, D. Léger, S. Dufour, A. G. Sheldon, D. T. Scholl, and H. W. Barkema. 2012. Antimicrobial use on Canadian dairy farms. J. Dairy Sci. 95:1209-1221. https://doi.org/10.3168/ jds.2011-4527.

Salasia, S. I., Z. Khusnan, C. Lammler, and M. Zschock. 2004. Comparative studies on pheno- and genotypic properties of Staphylococcus aureus isolated from bovine subclinical mastitis in central Java in Indonesia and Hesse in Germany. J. Vet. Sci. 5:103-109. https:/ /doi.org/10.4142/jvs.2004.5.2.103.

Schoenfelder, S. M., Y. Dong, A. T. Feßler, S. Schwarz, C. Schoen, R Köck, and W. Ziebuhr. 2017. Antibiotic resistance profiles of coagulase-negative staphylococci in livestock environments. Vet. Microbiol. 200:79-87. https://doi.org/10.1016/j.vetmic.2016.04.019.

Shin, J. H., S. H. Kim, H. S. Jeong, S. H. Oh, H. R. Kim, J. N. Lee, Y. C. Yoon, Y. W. Kim, and Y. H. Kim. 2011. Identification of coagulase-negative staphylococci isolated from continuous ambulatory peritoneal dialysis fluid using $16 \mathrm{~S}$ ribosomal RNA, tuf, and SodA gene sequencing. Perit. Dial. Int. 31:340-346. https://doi .org/10.3747/pdi.2010.00073.

Spanu, T., M. Sanguinetti, D. Ciccaglione, T. D'Inzeo, L. Romano, F. Leone, and G. Fadda. 2003. Use of the VITEK 2 system for rapid identification of clinical isolates of staphylococci from bloodstream infections. J. Clin. Microbiol. 41:4259-4263. https://doi.org/10 .1128/JCM.41.9.4259-4263.2003.

Stegger, M., P. S. Andersen, A. Kearns, B. Pichon, M. A. Holmes, G. Edwards, F. Laurent, C. Teale, R. Skov, and A. R. Larsen. 2012. Rapid detection, differentiation and typing of methicillin-resistant Staphylococcus aureus harbouring either mecA or the new mecA homologue mecALGA251. Clin. Microbiol. Infect. 18:395-400. https://doi.org/10.1111/j.1469-0691.2011.03715.x.

Stevens, M., S. Piepers, K. Supré, and S. De Vliegher. 2018. Antimicrobial consumption on dairy herds and its association with antimicrobial inhibition zone diameters of non-aureus staphylococci and Staphylococcus aureus isolated from subclinical mastitis. J. Dairy Sci. 101:3311-3322. https://doi.org/10.3168/jds.2017-13365.

Stevens, M., S. Piepers, K. Supré, J. Dewulf, and S. De Vliegher. 2016. Quantification of antimicrobial consumption in adult cattle on dairy herds in Flanders, Belgium, and associations with udder health, milk quality, and production performance. J. Dairy Sci. 99:2118-2130. https://doi.org/10.3168/jds.2015-10199.

Supré, K., S. De Vliegher, O. C. Sampimon, R. N. Zadoks, M. Vaneechoutte, M. Baele, E. De Graef, S. Piepers, and F. Hae- 
sebrouck. 2009. Technical note: Use of transfer RNA-intergenic spacer PCR combined with capillary electrophoresis to identify coagulase-negative Staphylococcus species originating from bovine milk and teat apices. J. Dairy Sci. 92:3204-3210. https://doi.org/ $10.3168 /$ jds.2008-1923.

Supré, K., F. Haesebrouck, R. N. Zadoks, M. Vaneechoutte, S. Piepers, and S. De Vliegher. 2011. Some coagulase-negative Staphylococcus species affect udder health more than others. J. Dairy Sci. 94:2329-2340. https://doi.org/10.3168/jds.2010-3741.

Tacconelli, E. 2009. Antimicrobial use: Risk driver of multidrug resistant microorganisms in healthcare settings. Curr. Opin. Infect. Dis. 22:352-358. https://doi.org/10.1097/QCO.0b013e32832d52e0.

Taponen, S., S. Nykäsenoja, T. Pohjanvirta, A. Pitkälä, and S. Pyörälä. 2016. Species distribution and in vitro antimicrobial susceptibility of coagulase-negative staphylococci isolated from bovine mastitic milk. Acta Vet. Scand. 58:12. https://doi.org/10.1186/s13028-016 -0193-8.

Unal, S., J. Hoskins, J. E. Flokowitsch, C. Y. Wu, D. A. Preston, and P. L. Skatrud. 1992. Detection of methicillin-resistant staphylococci by using the polymerase chain reaction. J. Clin. Microbiol. 30:1685-1691

Valckenier, D., S. Piepers, A. De Visscher, R. M. Bruckmaier, and S. De Vliegher. 2019. Effect of intramammary infection with nonaureus staphylococci in early lactation in dairy heifers on quarter somatic cell count and quarter milk yield during the first 4 months of lactation. J. Dairy Sci. 102:6442-6453. https://doi.org/10.3168/ jds.2018-15913.

Vanderhaeghen, W., T. Cerpentier, C. Adriaensen, J. Vicca, K. Hermans, and P. Butaye. 2010. Methicillin-resistant Staphylococcus aureus (MRSA) ST398 associated with clinical and subclinical mastitis in Belgian cows. Vet. Microbiol. 144:166-171. https://doi .org/10.1016/j.vetmic.2009.12.044.

Verbeke, J., S. Piepers, K. Supré, and S. De Vliegher. 2014. Pathogenspecific incidence rate of clinical mastitis in Flemish dairy herds, severity, and association with herd hygiene. J. Dairy Sci. 97:69266934. https://doi.org/10.3168/jds.2014-8173.

Waage, S., T. Mørk, A. Røros, D. Aasland, A. Hunshamar, and S. A. Odegaard. 1999. Bacteria associated with clinical mastitis in dairy heifers. J. Dairy Sci. 82:712-719. https://doi.org/10.3168/ jds.S0022-0302(99)75288-4.

Wang, D., L. Zhang, X. Zhou, Y. He, C. Yong, M. Shen, O. Szenci, and B. Han. 2016. Antimicrobial susceptibility, virulence genes, and randomly amplified polymorphic DNA analysis of Staphylococcus aureus recovered from bovine mastitis in Ningxia, China. J. Dairy Sci. 99:9560-9569. https://doi.org/10.3168/jds.2016-11625.

Wendlandt, S., J. Shen, K. Kadlec, Y. Wang, B. Li, W. J. Zhang, A. T. Feßler, C. Wu, and S. Schwarz. 2015. Multidrug resistance genes in staphylococci from animals that confer resistance to critically and highly important antimicrobial agents in human medicine. Trends Microbiol. 23:44-54. https://doi.org/10.1016/j.tim.2014.10.002.

Wilson, G.J., S.W. Tuffs, B.A. Wee, K.S. Seo, N. Park, T. Connelley, C.M. Guinane, W.I. Morrison, and J.R. Fitzgerald., 2018. Bovine Staphylococcus aureus superantigens stimulate the entire T cell repertoire of cattle. Infect. Immun. 86:e00505-18. https://doi.org/ 10.1128/iai.00505-18.

Wines, B. D., P. A. Ramsland, H. M. Trist, S. Gardam, R. Brink, J. D. Fraser, and P. M. Hogarth. 2011. Interaction of human, rat, and mouse immunoglobulin A (IgA) with staphylococcal superantigen-like 7 (SSL7) decoy protein and leukocyte IgA receptor. J. Biol. Chem. 286:33118-33124. https://doi.org/10.1074/jbc.M111 .272252 .

Wu, S., C. Piscitelli, H. de Lencastre, and A. Tomasz. 1996. Tracking the evolutionary origin of the methicillin resistance gene: Cloning and sequencing of a homologue of mecA from a methicillin susceptible strain of Staphylococcus sciuri. Microb. Drug Resist. 2:435-441. https://doi.org/10.1089/mdr.1996.2.435.

Wuytack, A., A. De Visscher, S. Piepers, F. Boyen, F. Haesebrouck, and S. De Vliegher. 2020. Distribution of non-aureus staphylococci from quarter milk, teat apices, and rectal feces of dairy cows, and their virulence potential. J. Dairy Sci. 103:10658-10675. https:// doi.org/10.3168/jds.2020-18265.

Yaw, L. K., J. O. Robinson, and K. M. Ho. 2014. A comparison of long-term outcomes after meticillin-resistant and meticillin-sensitive Staphylococcus aureus bacteraemia: An observational cohort study. Lancet Infect. Dis. 14:967-975. https://doi.org/10.1016/ S1473-3099(14)70876-X. 